\title{
HISTOMETERY OF TESTES AND ACCESSORY REPRODUCTIVE GLANDS OF MICE, EXPOSED TO THIODAN AND MALATHION.
}

\author{
I. A. Raja \\ Shri. Shivaji College, Akola, (MS), India. \\ Corresponding author Email : drad.bobdey@sscn.in
}

\begin{abstract}
:
The present study demonstrated Histometrical changes in testes, epididymis, and seminal vesicles of mice treated with different doses of Malathion and Thiodan for 63 days period. After 63 days, treated Mice were sacrificed, the testes epididymis, and seminal vesicles were fixed in vivo and were taken out. The histological slides of these organs were prepared and were studied under light microscope. In the present study both the experimental pesticides Thiodan and Malathion caused a dose related reduction in the seminiferous tubule diameters, and epithelial cell height in epididymis and seminal vesicles. These effects reflect the anti androgenic role played by these two pesticides in present study. Both the experimental pesticides are therefore seems to be toxic to male reproductive system on exposure. The awareness regarding the impact of such pesticides should be given to farmer and they should be encouraged to practice biological means to control pests and herbs.
\end{abstract}

\section{Keywords:}

Malathion, Thiodan, Laboratory mice, seminiferous tubules, Leydig`s cell, Epididymis, Seminal vesicles.

\section{Introduction:}

Pesticides are playing a pivotal role in meeting the food, cotton fiber and tobacco demand of escalating population and control of vector-borne diseases. However, most of the applied pesticides get dispersed in the environment and affects the health of un-protected agricultural and industrial workers. Exposure to pesticides is one of the most important occupational risks among farmers in developing countries (Wesseling et al., 2001; Konradsen et al., 2003; Coronado et al. 2004).Numerous incidents of acute Pesticidal poisoning have resulted from inhalation of sprays or contamination of crops or food. Malathion an organophosphate and Thiodan Organochlorine insecticides widely used throughout the world. Mostly used to control pests of agricultural crops, 
ornamentals, greenhouses, livestock, forests, buildings, households, and gardens. Malathion is a nerve toxin and damages the central nervous system (it inhibits the enzyme acetyl cholinesterase). Acute poisoning takes the form of bouts of sweating, increased production of saliva, diarrhea, bronchitis, heart attack and coma. Death occurs as a result of apnoea. There are no conclusive findings on teratogeny and fertility yet. Thiodan, an insecticide of cyclodiene group can be a potential environmental contaminant and may cause a public health hazard. Thiodan is an endocrine disruptor. It is estrogenic and antiandrogenic in human cells, and Causes breast cancer cells to grow. Mice have been selected for present study as they have a remarkable Genetic similarities to human.

\section{Material and Method:}

Only healthy males were housed in separate cages. The temperature of the house was maintained in the range of 200 to $250 \mathrm{C}$. The twelve hours of light and 12 hours of darkness was provided in the laboratory, for optimum growth and reproduction. The animals were fed on commercially available pellet. For inducing the reproductive toxicity by Thiodan and Malathion, a 63 days dose response chronic study was designed. The doses were prepared on the basis of lethal toxicity methods. All the animals were weighed and their initial body weight was recorded. The mice were divided into 7 groups, 06 animals/ group. Out of seven groups, one group (Group I) without any insecticide served as control group. Group II receive low dose of Thiodan, $(6.9 \mathrm{mg} / \mathrm{kg}$ body weight/ day) Group III medium dose of Thiodan, (13.8mg / $\mathrm{kg}$ body weight/ day)and Group IV received high dose of Thiodan, $(27.6 \mathrm{mg} / \mathrm{kg}$ body weight/ day ) Group V receive low dose of Malathion, ( $40 \mathrm{mg} / \mathrm{kg}$ body weight/ day) Group VI medium dose of Malathion, ( $80.6 \mathrm{mg} / \mathrm{kg}$ body weight/ day)and Group VII received high dose of Malathion, (161.2 $\mathrm{mg} / \mathrm{kg}$ body weight/ day )orally by gavages suspended in food as vehicle for a period of 63 days. Each animal was observed twice a day for clinical, toxicological, pharmacological symptoms and 
signs of specific toxicity if any, including behavioral abnormalities for Mobility and feeding. Reproductive organs, testes, epididymis, seminal vesicle, were cut in to small pieces, fixed in Bouins fixative for 12 to $24 \mathrm{hrs}$. Dehydrated, cleared and impregnated with paraffin wax and cast in to the blocks. The blocks were cut in to serial cross sections. The sections were deparaffinized and stained with haematoxylin / eosin .Finally analyzed for Histometrical alterations, with the help of ocular micrometer scale. Testicular cell population: In the cross sections of testis from all seven experimental groups of mice, 100 circular appearing seminiferous tubules were focused (x80). The diameter of each tubule was measured. The measurement was expressed in terms of mean of all the focused tubules. The dimensions of Leydig"s cell nuclei were measured with the help of ocular micrometer (x80). Similarly the epithelial cell height of cauda epididymis, caput epididymis and seminal vesicle were also calculated with the help of ocular micrometer.

\section{Result and Discussion:}

$\mathrm{m}$ in mice from group VI and VII respectively. Leydig`s cell nucleus diameters: A dose dependent reduction in the nuclear diameter is observed as compared with the control group of mice. the range of reduction in Leydig's cell nuclear diameter was depicted in the table,. The range of reduction was lesser in low dose but become significantly reduced in the mice from higher dose groups. Epithelial cell height in caput epididymis: The exposure with both pesticides caused a significant decrease in the epithelial cell height of the caput epididymis when compared with the control mice. Seminal vesicle epithelial cell height in Thiodan fed mice: As presented in the table though low dose of pesticides had nothing to do with the epithelial cell height in seminal vesicle. But the medium and high doses of both pesticides caused a considerable reduction on this parameter, when compared with the control mice. Similarly there was significant reduction observed in the glandular epithelial cell nuclear diameter in all treated mice. As compare to control mice. Pesticides induced 
reduction in the male reproductive organ tissue dimensions, have been noticed by a number of workers, ( Bal, 1984 ; Chaudhary, et al., 1986 ; Chapin et al., 1996 ; Somkuti, et al., 1991 ; Akbar Shah, and Sivswamy ;1997 and Faqui, et al., 1998). In accordance with these, in the present study both the experimental pesticides Thiodan and Malathion caused a dose related reduction in the seminiferous tubule diameters, and epithelial cell height in epididymis and seminal vesicles. Histometrical deformities observed in the seminiferous tubules in the testes could be due to the disturbed pituitary gonadotrophin secretion, (Chinoy and Smith, 1977 and Cochran and Wiedow, 1986)). Both the pesticides Thiodan and Malathion exposure might impair the Leydig"s cells function as evident by their reduced size resulting in decreased production of androgen, Khawla, et al., (1987). Chapin, (1990), also observed decrease Leydig"s cell nuclear diameter, in rats after exposure to an organophosphate toxicant tri-o-crysyl phosphate. Androgen in combination of FSH acts on spermatogenesis, (Davies, 1981). FSH increases the formation of Sertoli cells structural protein and androgen binding protein. (ABP). The ABP is responsible for the transportation of androgen to the lumen of the epididymis. FSH influences the development of interstitial tissue by inducing luteinizing hormone (LH) receptors and Leydig"s cells. The degree of restoration of accessory gland is proportional to the amount of androgen, (Turner, 1966), therefore the reduction in the seminiferous tubules and Leydig"s cell nuclear diameter in present study is indicative of disturbances in FSH androgen action. Administration of Thiodan and Malathion in male mice resulted in reduction of epithelial cell height in epididymis. The lumen was also deprived of secretion. Such effects could be due to androgen deprivation, (Rajlakshmi and Prasad, 1975). Exposure with pesticides, Thiodan and Malathion induced reduction in epithelial cell height in seminal vesicles. These effects reflect again the anti androgenic role played by these two pesticides in present study. Since the accessory sex organs are classic target for androgen, their weight as well as function are naturally influenced by antiandrogen, (Neuman and Steinbeack, 
1974). Similarly a significant decrease in the secretary capacity of the accessory glands has also been reported in mice and gerbil following the administration of well known antiandrogen Solasodin (Dixit and. Gupta, 1982) Such results has also been derived by Nupur and Nath (1999), on the mice exposed to Malathion. Thomas and Lloyd, (1973) has also reported these effects with DDT, dieldrin and parathion treatments in rats and mice. $\mu \mathrm{m}, 60.73, \mu \mathrm{m}$. But increasing doses of Malathion proved significantly damaging as the diameter of seminiferous tubules" reduced to $82.32 \mu \mathrm{m}$. Thought Malathion is toxic to seminiferous hypsometry low dose caused a least effects on dimension of seminiferous tubules" which was calculated to be $135, \mu \mathrm{m}$ as compared to control mice. ie. $168.8 \mu \mathrm{m}$ and $50.72 \mu \mathrm{m}, 56.02, \mu$ Seminiferous tubules

Diameter: As shown in the table, the diameter of the seminiferous tubules in all the mice treated with all doses of Thiodan was reduced significantly when compared with the control mice. The range of reduction in the mice from II III and IV was 69.7,

\section{Conclusion:}

From this study it can be concluded that both the experimental pesticides are therefore seems to be toxic on male reproductive system on exposure. The awareness regarding the possible impact of such pesticides should be given to farmer in the rural areas and they should be encouraged to practice biological means to control pests and herbs instead of these harmful chemical compounds. These pesticides either inhibit androgen secretion followed by the reduction in LH levels or they have a direct effect on testosterone biosynthesis.

\section{Acknowledgement:}

Author is thankful of Principal Shivaji College, Akot for the cooperation and Dr. A. D. Bobdey Head Department of Zoology, Science College Nagpur-12 for their valuable encouragement and suggestions throughout the work. 


\section{Reference:}

Akbarsha, M.A.and Sivaswamy, P. (1997): Apoptosis in male germinal line cells of rat in vivo: caused by phosphamidon. Cytobios. 91(364): 33-44.

Bal, H.S. (1984): Effect of methoxychlor on reproductive systems of the rat. Proc Soc Exp Biol Med 176: 187-196.

Chapin R. E., J.L. Phelps, S.G. Somkuti, J.J. Heindel, L.T. Burka.(1990) : The interaction of Sertoli and Leydig cells in the testicular toxicity of tri-ocresyl phosphate.Toxicol Appl Pharmacol.104(3) : 483-95.

Chowdhary A.R. , K.D. Vachhrajani., S. Makhija, S.K. Kashyap. (1986) : Histomorphometric and biochemical changes in the testicular tissues of rats treated with mercuric chloride. Biomed Biochim Acta.45 (7): 949-56.

Chinoy, N.J. and Seth, K.M. (1977): Studies on the effects of drugs on accessory reproductive gland function of Rodents III: Narcotics and Analogesic Drug. Comp. Physiol. Ecol. 2: 1-7.

Cochran R.C., and M.A. Wiedow. (1986): The effects of Tris(2,3-Dibromoprophl) Phosphate on the Reproductive System of Male Rats. J of the Amrican College of Toxicol.5 (2): 153-160

Coronado, G.D.; Thompson, B. Strong, L. Griffith, W.C. Islas, I. (2004). Agricultural task and exposure to organophosphate pesticides among farm workers. Environ. Health Persp., 112., 142-14

Davies, A.G. (1981): Role of FSH in the control of testicular function. Archives of andrology. 7: 97-108.

Dixit, V.P. and Gupta, R.S. (1982) : Antispermatogenic / Antiandrogenic properties of Solasodine ( C27H43O2N) obtained from Solanum xnthocarpus berries on the male genital tract of dog (Cannis familiast) Ind. J. Andrology. $5: 595-307$. 
Faqi A.S., P.R. Dalsenter, W. Mathar, B. Heinrich-Hirsch, I.Chahoud. (1998): Reporductive toxicity and tissue concentrations of $3,3^{\prime}, 4,4^{\prime}$ tetrachlorobiphenyl (PCB 77) in male adult rats. Hum Exp Toxicol, 17: 131-137.

Khawla J.Balash, Muthanna A. Al-Omar, and Baslma, M. Abdul Latif. (1987): Effect of Chlordane on Testicular Tissues of Swiss Mice. Bull, Environ, Contam, Toxicol. 39: 434-442.

Konradsen, F., Van der Hoek, W. Cole, D.C. Hutchinson, G. 1 Daisley, H.; Singh, S., Eddleston, M. (2003). Reducing acute poisoning in developing countries-options for restricting the availability of pesticides. Toxicology, 192. 249-261.

Neumann, F. and Steinbeck, H. (1974): Antiandrogen. In : Hand book of Expermental pharmacology (O. Eichler, A., Farh, H., Iterken, and A.D. Welch, Eds.) springer, Berlin. Vol 35, pp.235-484.

Nuppur Lal and Nath, A. (1998): Effect of organophosphorus Insecticide malathion on seminal vesicles.

Rajalakshmi, M. and Prasad, M.R.N. (1975) : Changes in Sialic acid in testes and epididymis of rats during onset of puberty. J. Endocr. 44: 379-385.

Somkuti S.G., D. M. Lapadula, R.E. Chapin, M.B. Abou-Donia., (1991) : Light and electron microscopic evidence of tri-o-cresyl phosphate (TOCP) mediated testicular toxicity in Fischer 344 rats. Toxicol Appl Pharmacol.107(1) : 35-46.

Thomas JA Lloyd JW, (1973): Organochloride Pesticides And Sex Accessory Organs Of Reproduction. Exposure with pesticides, Thiodan and Malathion induced reduction in epithelial cell height in seminal vesicles. These effects reflect again the anti androgenic role played by these two pesticides in present study. Pesticides and the Environment, A Continuing Controversy, 2: 43-51, 
Turner, C.D., (1966) : Endocrinology of the testis. In : General Endocrinology, 4th Ed. W.B. Saunders Company Philadelphia. London. Pp. 423. Vesicle of mice. Mus musculus Environmental and ecology 16 (4):805-808.

Wesseling, C.; Aragon, A.; Castillo, L.; Corrals, M.; Chaverri, F.; de la Cruz, E.; Keifer, M.; Monge, P.; Partanen, T.J.; Ruepert, C.; van Wendel de Joode, B. (2001). Hazardous pesticides in Central America. Int. J. Occup. Environ. Health 7. 287-29

Table: Histometery of Testes and accessory reproductive glands of male mice, exposed to Thiodan and Malathion.

\begin{tabular}{|c|c|c|c|c|c|}
\hline Condition & Group & $\begin{array}{l}\text { Seminiferous tubules } \\
\text { diameter in } \mu \mathrm{m}\end{array}$ & $\begin{array}{l}\text { Leydig's cell nuclear } \\
\text { diameter in } \mu \mathrm{m}\end{array}$ & $\begin{array}{c}\text { Caput } \\
\text { epididymis } \\
\text { epithelial cell }\end{array}$ & $\begin{array}{c}\text { Seminal vesicle } \\
\text { epithelial cell height } \\
\text { in } \mu \mathrm{m}\end{array}$ \\
\hline Control & I & $\begin{array}{l}168.60 \\
\pm 0.48\end{array}$ & $\begin{array}{r}6.45 \\
\pm 0.7\end{array}$ & $\begin{array}{c}36.5 \\
\pm 1.02\end{array}$ & $\begin{array}{l}17.32 \\
\pm 0.17\end{array}$ \\
\hline \multirow{3}{*}{$\begin{array}{l}\text { Thiodan } \\
\text { exposed }\end{array}$} & II & $\begin{array}{r}69.27 \\
+3.55 \\
\end{array}$ & $\begin{array}{c}3.79 \\
+0.74 \\
\end{array}$ & $\begin{array}{r}24.68 \\
+2.66\end{array}$ & $\begin{array}{l}13.45 \\
\pm 0.27\end{array}$ \\
\hline & III & $\begin{array}{l}56.72 \\
\pm 2.20\end{array}$ & $\begin{array}{c}3.27 \\
\pm 0.55 \\
\end{array}$ & $\begin{array}{r}16.66 \\
\pm 1.74 \\
\end{array}$ & $\begin{array}{r}12.89 \\
\pm 0.08 \\
\end{array}$ \\
\hline & IV & $\begin{array}{l}50.72 \\
\pm 2.93\end{array}$ & $\begin{array}{c}2.96 \\
\pm 0.54\end{array}$ & $\begin{array}{r}12.66 \\
\pm 0.87\end{array}$ & $\begin{array}{r}10.46 \\
\pm 0.11\end{array}$ \\
\hline \multirow{3}{*}{$\begin{array}{l}\text { Malathion } \\
\text { exposed }\end{array}$} & V & $\begin{array}{l}135.78 \\
\pm 4.57\end{array}$ & $\begin{array}{l}4.62 \\
\pm 0.5\end{array}$ & $\begin{array}{c}26.3 \\
\pm 0.37\end{array}$ & $\begin{aligned} & 16.5 \\
\pm & 0.87\end{aligned}$ \\
\hline & VI & $\begin{array}{r}82.32 \\
\pm 3.02\end{array}$ & $\begin{array}{c}3.91 \\
\pm 0.52\end{array}$ & $\begin{array}{c}22.2 \\
\pm 0.72\end{array}$ & $\begin{array}{r}16.72 \\
\pm 1.68\end{array}$ \\
\hline & VII & $\begin{array}{r}60.73 \\
\pm 2.33\end{array}$ & $\begin{array}{c}3.01 \\
\pm \quad 0.43\end{array}$ & $\begin{array}{c}17.3 \\
\pm 0.97\end{array}$ & $\begin{array}{l}12.37 \\
\pm 2.16\end{array}$ \\
\hline
\end{tabular}

